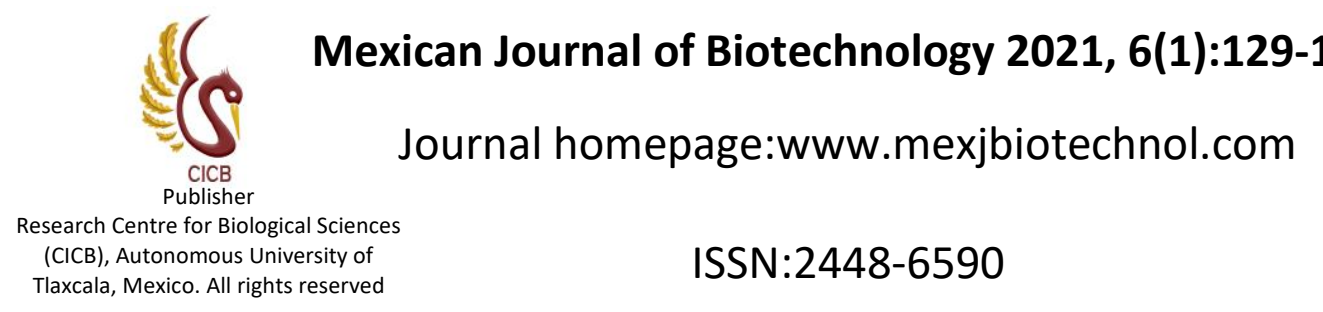

REVIEW ARTICLE

\title{
Saving the planet with appropriate biotechnology: 4. Coccolithophore cultivation and deployment
}

\section{Salvando el planeta con biotecnología apropiada: 4. Cultivo de cocolitóforos e implementación}

David Moore

School of Biological Sciences, Faculty of Biology, Medicine and Health, The University of Manchester, UK (retired).

${ }^{*}$ Corresponding author

E-mail address: david@davidmoore.org.uk (D. Moore)

Article history:

Received: 12 October 2020 / Received in revised form: 10 December 2020 / Accepted: / 23 December 2020 / Published online: 1 January 2021.

https://doi.org/10.29267/mxjb.2021.6.1.129

\begin{abstract}
Cultivating coccolithophore algae for carbon sequestration is discussed. Coccolithophores have been major calcium carbonate producers in the world's oceans for about 250 million years. Today, they account for about a third of the total marine $\mathrm{CaCO}_{3}$ production by coating their single cells externally with plates of microcrystalline $\mathrm{CaCO}_{3}$. The possibility that these algae could be used to trap atmospheric $\mathrm{CO}_{2}$ with existing technology has not been widely considered. There is scope for both high technology cultivation in bioreactors and low technology cultivation in terraced raceway ponds or lagoons on tropical coastal sites. The latter could produce a sludge of pure $\mathrm{CaCO}_{3}$ as a feedstock for cement production in place of the fossilised limestone currently used (cement production accounts for around $8 \%$ of industrial fossil $\mathrm{CO}_{2}$ emissions). On the high seas coccolithophores naturally produce extensive blooms, which emit the volatile gas dimethyl sulfide to the atmosphere, where it promotes formation of clouds that block solar radiation. The vision is for aquaculture nurseries onboard factory ships, cultivating both coccolithophores and bivalve molluscs, creating and maintaining blooms of coccolithophores in the oceanic high seas to sequester carbon from the atmosphere and generate cloud cover to cool the immediate environment.
\end{abstract}

Keywords: aquaculture, atmosphere remediation, bivalve farm, carbon dioxide, global warming, habitat restoration. 


\section{RESUMEN}

Se discute el cultivo de las algas cocolitóforos para el secuestro de carbono. Los cocolitóforos han sido los principales productores de carbonato de calcio en los océanos del mundo durante unos 250 millones de años. Hoy en día, representan alrededor de un tercio de la producción total de $\mathrm{CaCO}_{3}$ marino cubriendo sus celdas individuales externamente con placas de $\mathrm{CaCO}_{3}$ microcristalino. No se ha considerado ampliamente la posibilidad de que estas algas puedan utilizarse para atrapar el $\mathrm{CO}_{2}$ atmosférico con la tecnología existente. Se puede llevar a cabo el cultivo empleando alta tecnología en biorreactores, así como el cultivo de baja tecnología en estanques o lagunas en terrazas en sitios costeros tropicales. Este último podría producir un sedimento de $\mathrm{CaCO}_{3}$ puro como materia prima para la producción de cemento en lugar de la piedra caliza fosilizada utilizada actualmente (la producción de cemento representa alrededor del $8 \%$ de las emisiones de $\mathrm{CO}_{2}$ procedentes de la actividad industrial y de los combustibles fósiles). En alta mar los cocolitóforos producen naturalmente extensas floraciones, que emiten el gas volátil sulfuro de dimetilo a la atmósfera, el que promueve la formación de nubes que bloquean la radiación solar. La visión es que los viveros de acuicultura a bordo de los buques factoría, cultiven tanto cocolitóforos como moluscos bivalvos, creando y manteniendo floraciones de cocolitóforos en alta mar oceánica para secuestrar carbono de la atmósfera y formar nubes para enfriar el ambiente inmediato.

Palabras clave: acuicultura, remediación de la atmósfera, cultivo de bivalvo, dióxido de carbono, calentamiento global, restauración del hábitat.

\section{Introducing calcifying algae}

The only publication that recognises the true potential for marine calcification to remove $\mathrm{CO}_{2}$ from the atmosphere...' is Steve Connor's Science News article in The Independent newspaper entitled 'Can seashells save the world?' (Connor, 2008). In this article, Steve Connor explains that "... coccolithophores are microscopic marine plants that convert carbon dioxide into chalk. It was thought that rising $\mathrm{CO}_{2}$ and more acid oceans would curb their activity. Instead, they are booming - and fighting global warming ..." and that "... these tiny photosynthetic organisms play a critical role in banking huge amounts of carbon by growing in huge numbers. Indeed, coccolithophore 'blooms' are so big they can even be seen from space ..." (Connor, 2008).

Connor (2008) quotes Paul Halloran of Oxford University, a co-author of Iglesias-Rodriguez et al. (2008) as stating that coccolithophores have thrived during the recent increases of atmospheric $\mathrm{CO} 2$ since the start of the Industrial Revolution; adding: "Our research has also revealed that, over the past 220 years, coccolithophores increased their mass of calcium carbonate by 40 per cent. These results are in agreement with previous observations of coccolithophores being abundant in a period of ocean acidification 55 million years ago."

Connor's final paragraph warns that "... The coming century could see carbon dioxide levels in the atmosphere rising to 600 parts per million and beyond - which is unprecedented in terms of the human timescale on this planet. So, the question of how marine calcifiers will cope with this change will be critical in terms of whether the earth's oceans will continue to help us to deal with our carbon dioxide emissions ..."

This review offers a brief description of the nature and biology of coccolithophores and makes some suggestions about how they could be harnessed to save the world. Table 1 notes a few YouTube videos you might like to view. 


\section{The nature, biology and ecology of coccolithophores}

Coccolithophores are eukaryotic phytoplanktonic algae that are predominantly found as single, free-floating haploid or diploid cells (Geisen et al. 2004). Originally assigned to the kingdom Protista, they are now usually included in the subkingdom Hacrobia, phylum Haptophyta. Hacrobia is assigned to the Chromalveolate supergroup (though the status of this assemblage is uncertain as it may not be monophyletic). Haptophyte cells have two large golden-brown chloroplasts located on either side of the cell and surrounding the nucleus, mitochondria, golgi apparatus, endoplasmic reticulum, and other organelles. The cells have two slightly unequal, smooth flagella, and a unique organelle called a haptonema, for which the phylum is named. A haptonema is a threadlike organelle, that extends from a position between the bases of the two flagella. Superficially similar to a flagellum, it differs in the arrangement of microtubules. It is more than $100 \mu \mathrm{m}$ long in some species, and a variety of functions have been demonstrated: attachment and gliding on a substrate, formation of food aggregates, food capture and transport, and reception of mechanical stimuli. The haptonema is capable of rapid coiling movements that occur within a few milliseconds following mechanical stimulation which is suggested to depend on $\mathrm{Ca}^{2+}$-binding microtubule-associated proteins (Nomura et al., 2019).

\begin{tabular}{|l|c|}
\hline Table 1. YouTube videos about coccolithophores & $\begin{array}{c}\text { CLICK } \\
\text { LINK }\end{array}$ \\
\hline $\begin{array}{l}\text { Coccolithophores and Calcium. From coccolithophores to the White Cliffs of Dover, } \\
\text { physicist Helen Czerski explains the amazing cycle that makes Calcium her favourite } \\
\text { element. [https://www.youtube.com/watch?v=EMNuYOEBOWI] }\end{array}$ & LINK \\
\hline $\begin{array}{l}\text { Aliza Fassler's Diatoms, Coccolithophores \& Climate Change. This video is about } \\
\text { how climate change will affect diatoms and coccolithophores. Changes in the } \\
\text { abundance of diatoms and coccolithophores will affect carbon cycling and } \\
\text { sequestration [https://www.youtube.com/watch?v=KfQz16LyPP4] }\end{array}$ & LINK \\
\hline $\begin{array}{l}\text { American Geophysical Union's Giant algal bloom sheds light on formation of White } \\
\text { Cliffs of Dover [https://www.youtube.com/watch?v=Ep5tcBXyFoE] }\end{array}$ & $\underline{ }$ \\
\hline
\end{tabular}

The majority of known haptophytes occur as marine coastal, or open oceanic, planktonic organisms, although a few species thrive in freshwater (Sáez et al. 2004). Many can form massive blooms, which in some cases are a hazard for commercial fisheries and other natural biota (Fig. 1). The best-known haptophytes are those that have an exoskeleton of calcareous plates called coccoliths; these are the coccolithophores and they account for 673 of the 762 described species of haptophytes (Foissner, 2005).

The distinguishing feature of coccolithophores is that the algal cell is enclosed by a cage of intricate calcium carbonate plates (or scales), which make up the enclosing structure, which is called a coccosphere. The coccoliths are constructed from nanocrystals of $\mathrm{CaCO}_{3}$, and are transparent so they do not shade the chloroplasts which need light for photosynthesis. In fact, the calcite in calcium carbonate allows coccoliths to scatter more light than they absorb, and this scattering enables satellite images to track coccolithophore blooms (Fig. 1). A high concentration of coccoliths increases the temperature of surface water and decreases the temperature of deeper waters; resulting in greater stratification of the water column and decreased vertical mixing. 


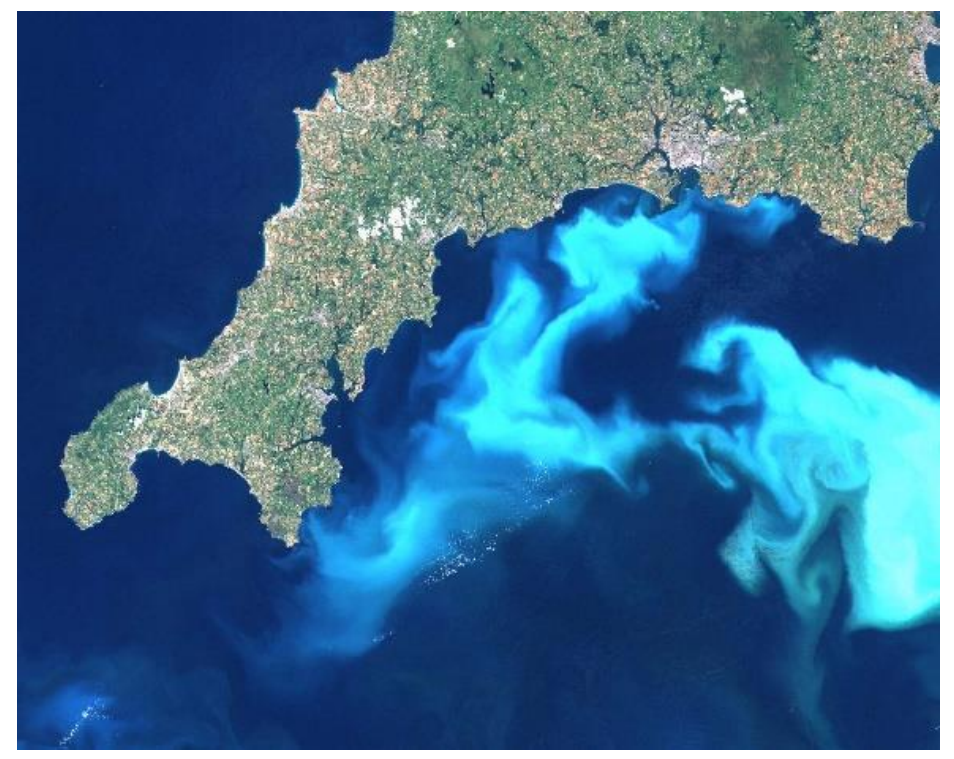

Fig. 1. LANDSAT Satellite image of Emiliania huxleyi bloom in the English Channel off the coast of Cornwall, 24th July 1999. What look like pale blue clouds in the water are, in fact, the reflected light from billions of coccoliths floating in the water-column. (Photo: NASA, text by Steve Groom, Plymouth Marine Laboratory; image source: https://commons.wikimedia.org/wiki/File:Cwall99 lg.jpg under Creative Commons license CC-BY-SA 3.0).

However, recent estimates of the overall effect of coccolithophores on ocean temperatures is that it is less than that from anthropogenic sources (Morrissey et al., 2016). Consequently, rather than contributing to global warming, large blooms of coccolithophores cause a decrease in water column productivity in the deeper layers because less light penetrates to them. There seem to be no reports of coccolithophore toxicity, although closely related algae do produce haemolytic compounds that have been responsible for large fish kills and accumulate through the food chain. But toxicity tests in the laboratory with members of the oceanic coccolithophores Emiliania, Gephyrocapsa, Calcidiscus and Coccolithus, and the coastal genus Hymenomonas, showed them to be non-toxic. Though the coastal genera Pleurochrysis spp. and Jomonlithus spp., were both toxic to the brine shrimp Artemia (Houdan et al., 2004).

One suggested function of the coccoliths is to act as lenses to focus illumination on the photosynthetic apparatus, enabling the cell to thrive in deeper zones where light levels are lower but nutrient levels higher than in surface waters, but several other potential functions have been suggested. These include isolating the intracellular environment from the marine; protection from osmotic, chemical and/or mechanical stress; protection from UV in sunlight; protection from predators among the zooplankton (coccolith appendages may hinder grazing by zooplankton); and it has also been proposed that coccoliths may allow the cell to control its buoyancy, perhaps enabling it to sink to deeper nutrient rich levels in the water while avoiding descent to dangerous depths (Irie et al., 2010; Young et al., 2009).

Coccolithophores are almost exclusively marine and are found in large numbers throughout the sunlight zone of the world oceans and because of this production of calcite coccoliths, they are both (i) the largest atmospheric carbon sinks, and (ii) one of the largest primary producers on the planet, making them major contributors to global ocean calcification and long-term carbon fluxes. They can also form large amounts of lipids, especially long chain omega-3 polyunsaturated fatty acids (LC-PUFA or 'fish oils'), which have a high potential value as supplementary dietary nutrients. Consequently, in addition to their primary producer's algal 
photosynthesis and role as the ocean's major resource for calcification, they could also serve as a renewable fuel and alternative food source (Moheimani et al. 2012).

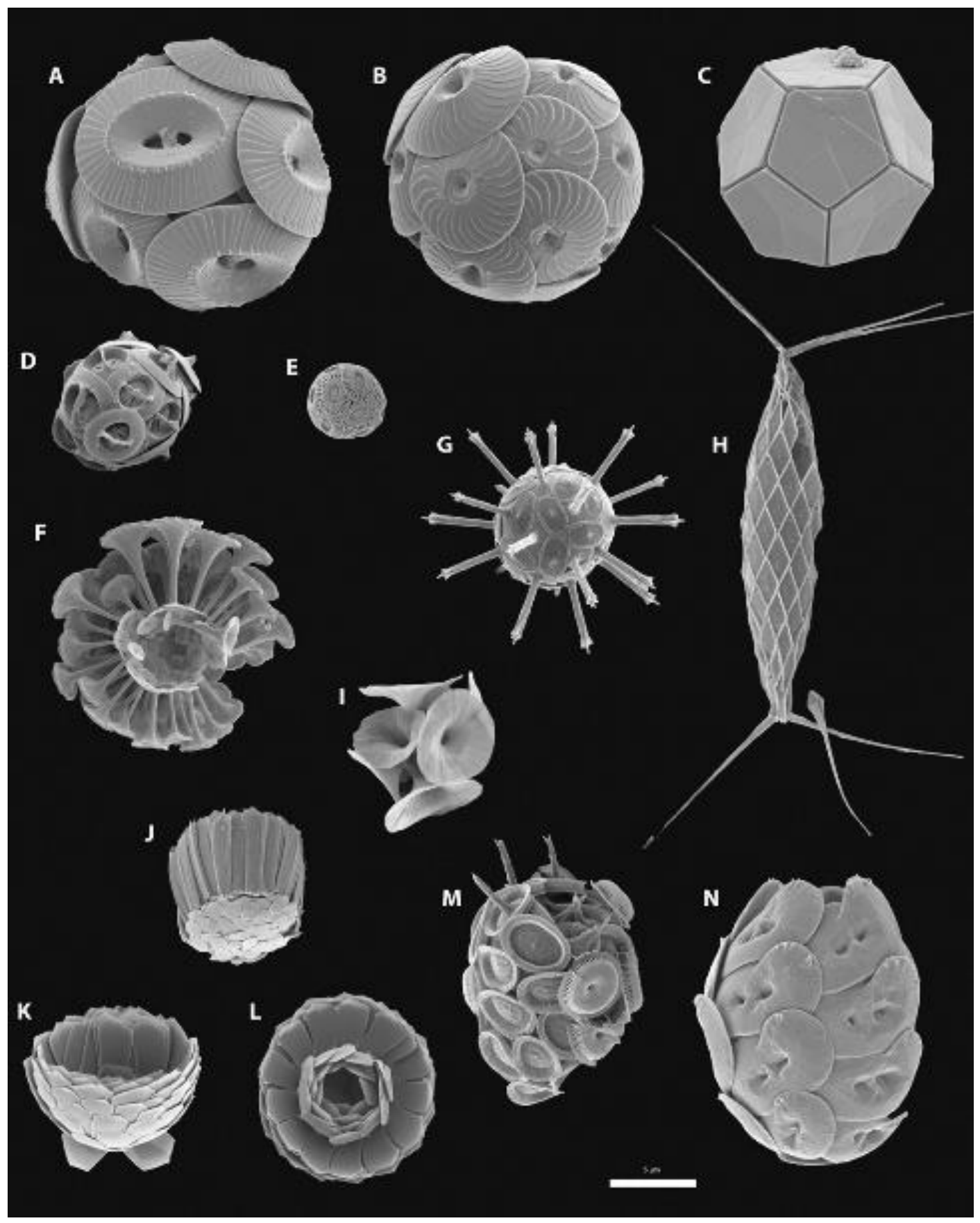

Fig. 2. Diversity of modern coccolithophores. All images are scanning electron micrographs of cells collected by seawater filtration from the open ocean. Species illustrated: (A) Coccolithus pelagicus, (B) Calcidiscus leptoporus, (C) Braarudosphaera bigelowii, (D) Gephyrocapsa oceanica, (E) Emiliania huxleyi, (F) Discosphaera tubifera, (G) Rhabdosphaera clavigera, (H) Calciosolenia murrayi, (I) Umbellosphaera irregularis, (J) Gladiolithus flabellatus, (K and L) Florisphaera profunda, (M) Syracosphaera pulchra, and (N) Helicosphaera carteri. Scale bar, $5 \mu \mathrm{m}$. Image from Monteiro et al. (2016) under a Creative Commons Attribution 4.0 International License (https://creativecommons.org/licenses/by/4.0/). 
A Coccolithophore species richness
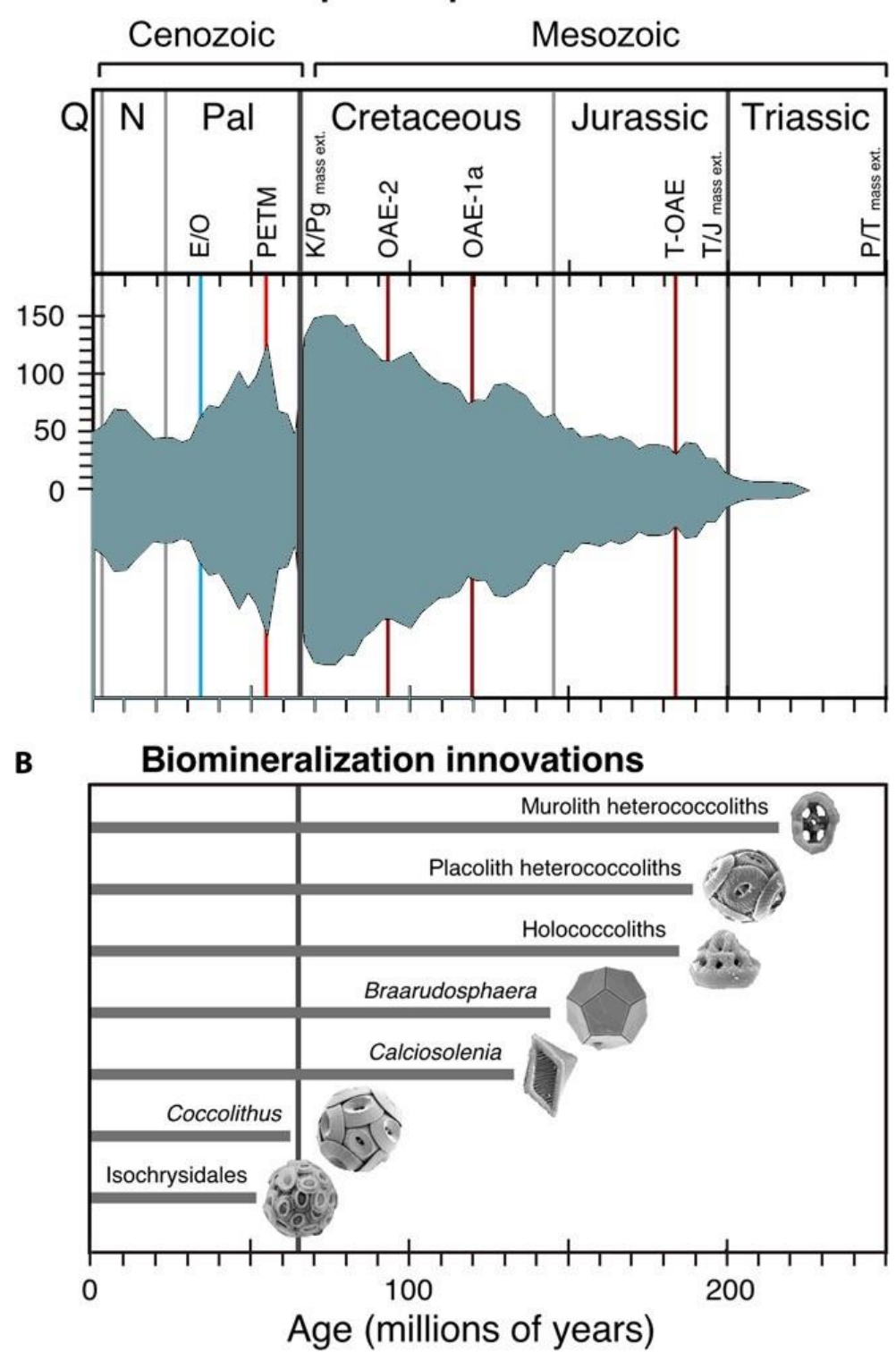

Fig. 3. Evolutionary history of coccolithophores. The top panel (A) shows species richness over time. $\mathbf{Q}$, Quaternary; N, Neogene; Pal, Paleogene; E/O, Eocene/Oligocene glacial onset event; PETM, Paleocene/Eocene thermal maximum warming event; K/Pg, Cretaceous/Paleogene; OAE, oceanic anoxic event; T-OAE, Toarcian oceanic anoxic event; T/J, Triassic/Jurassic; P/T, Permian/Triassic; mass ext., mass extinction.

Panel B summarises the fossil record of major coccolithophore biomineralisation innovations and morphological groups, including the first appearances of muroliths (simple coccoliths with narrow, walllike rims), placoliths (coccoliths with broad shields that interlock to form strong coccospheres), holococcoliths (coccoliths formed from microcrystals in the haploid life cycle phase), Braarudosphaera (pentagonal, laminated nannoliths forming dodecahedral coccospheres); Calciosolenia (distinct, rhombic murolith coccoliths), Coccolithus (long-ranging and abundant Cenozoic genus), Isochrysidales (dominant order that includes Emiliania, Gephyrocapsa, and Reticulofenestra). Significant mass extinctions and paleoceanographic/paleoclimatic events are marked as horizontal lines. Data from Bown et al. (2004); graphic from Monteiro et al. (2016) under a Creative Commons Attribution 4.0 International License (https://creativecommons.org/licenses/by/4.0/). 
Morphologically, all coccolithophores share the same basic structure of a cell surrounded by the exoskeletal coccosphere, but coccosphere shapes range from spherical to cylindrical, with sizes ranging from about 3 to $30 \mu \mathrm{m}$. The number of coccoliths making up a coccosphere varies from as few as six to several hundred, in either one or many layers. The coccoliths themselves range from simple discs to those with elaborate ornamentations, including spines and other projections, and delicate grilles. All of this results in a remarkable morphological diversity within the group (Fig. 2). However, environmental DNA sequencing shows even greater diversity in the coccolithophores of the marine plankton, many of which sequences are likely to represent novel species and lineages.

Coccolithophores are abundant in the marine phytoplankton, especially in the open ocean, and in the present day, sedimented coccoliths are a major component of the calcareous sediments that cover up to $35 \%$ of the ocean floor, being kilometres thick in some places (de Vargas et al., 2007). This abundance and wide geographic distribution are preserved into the fossil record resulting in coccoliths being the main component of the Late Cretaceous Chalk, a rock formation which outcrops widely in southern England, forming the White Cliffs of Dover, and other similar rocks in many other parts of the world (Chimileski \& Kolter, 2017). Species diversity is believed to have peaked in the past and their presence is documented in the fossil record back to the Triassic, approximately 225 million years ago (Fig. 3). Some of their biomolecules are extraordinarily resistant to decay and are thus used by geologists as sedimentary representations of past climatic conditions (Eikrem et al., 2017)

The most abundant species of coccolithophore, Emiliania huxleyi (image $\mathbf{E}$ in Fig. 2) occurs in the plankton of almost all ocean ecosystems from the equator to sub-polar regions, and from nutrient-rich upwelling zones to nutrient-poor oligotrophic waters, which makes $E$. huxleyi an important primary producer at the root of a great many marine food webs around the world (Foissner, 2005).

Emiliania huxleyi has been widely studied as a model organism to understand physiological, biogeochemical, and ecological processes in the oceans, because:

- It is easily cultured in vitro and, in fact, was the fastest growing coccolithophore among the six laboratory cultures studied by Buitenhuis et al. (2008).

- The extensive blooms it forms in nutrient depleted waters after the reformation of the summer thermocline (Chimileski \& Kolter, 2017) have been studied using floating laboratories with sea enclosures (Egge \& Aksnes, 1992).

- Long-term trends in surface winter nutrients and summer oxygen concentration of the euphotic zone, as well as seasonal and interannual variability in surface chlorophyll a (chl a) have been investigated for different shelf regions (depths less than $50 \mathrm{~m}$ ) of the western Black Sea (Yunev et al. 2007). They showed that decrease in the silica to nitrogen ratio, caused by the numerous dams constructed on the River Danube, provoked a shift towards greater non-siliceous phytoplankton blooms (that is, from diatom blooms to haptophyte blooms). Phytoplankton need sunlight and nutrients from the ocean to survive, so they thrive in areas with large inputs of nutrient rich water upwelling from the lower levels of the ocean. The ratios between nitrogen, phosphorus and silicate concentrations determines competitive dominance between different phytoplankton communities by favouring either diatoms or other phytoplankton, such as coccolithophores. A low silicate to nitrogen and phosphorus ratio allows coccolithophores to outcompete diatoms, when silicate to phosphorus and nitrogen ratios are high coccolithophores are outcompeted by diatoms.

- Other sources of nutrients, such as inputs from shelf sediments and/or upwelling, and those related to the Danube River maximum discharge levels during spring, contributed to 
seasonal variations in chlorophyll-a measurements (used as a measure of phytoplankton concentration).

- It has been demonstrated that haptophyte pigments and $\mathrm{C}_{37}-\mathrm{C}_{38}$ alkenones (long-chain biolipids) are synthesised at the seawater layers of highest primary production and therefore the $\mathrm{C}_{37}$ alkenone record reveals the temperature for the highest primary productivity of shallow $(5 \mathrm{~m})$ or deep $(1100 \mathrm{~m})$ waters. Due to their high resistance to chemical and microbial degradation these alkenone molecules are commonly used by earth scientists studying global climate change as a means to estimate past sea surface temperatures (Bentaleb et al. 1999).

- Today, coccolithophores contribute to ocean temperature regulation. They grow well in warm seas and algal blooms produce large amounts of dimethyl sulfide (DMS), a volatile gas that is emitted to the atmosphere, where it promotes formation of clouds that block solar radiation. As the oceans then cool, the coccolithophore populations decrease and cloud cover also decreases because of the reduced levels of DMS. A classic feedback loop maintaining the temperature equilibrium of the seas (Keller, 1989; Alcolombri et al., 2015).

- Coccolithophores, as calcifiers, have been such an important component of the Earth's carbon balancing system for hundreds of millions of years that they are naturally of particular interest for studies of contemporary global climate change. This is particularly true because of the widely expressed fear that as ocean acidity increases, coccolithophores may become less calcified. However, a detailed study of the most abundant coccolithophore species, Emiliania huxleyi, in the Bay of Biscay revealed a pronounced seasonality in the morphology of the individuals in the population. In summer, the heavily calcified morphology accounted for only $10 \%$ of the population, whereas in winter, when the waters were most acidic and $\mathrm{CaCO}_{3}$ saturations were at their lowest, the population shifted to be $90 \%$ of the heavily calcified form. In other words, the most heavily calcified morphotype dominates when conditions are most acidic, which is contrary to the earlier fears and predictions for a high- $\mathrm{CO}_{2}$ world, suggesting that even in more acidic conditions, coccoliths may be important as a carbon sink (Smith et al., 2012).

More recent work suggests, though, that Emiliania huxleyi is not one species, but a family group of closely-related species (a species complex). Genomic analysis has shown that different $E$. huxleyi strains harbour extensive genome variability, implying that the strains are isolates from a species complex rather than a single species. The genome variability is reflected in the phenotypic variability, demonstrated as inter-strain variability in physiological and biogeochemical traits in strains maintained in different culture collections (Blanco-Ameijeiras et al., 2016), resulting from different metabolic capabilities that allow E. huxleyi to thrive in habitats ranging from the equator to the subarctic and enabling the 'species' to form large-scale episodic blooms under a wide variety of environmental conditions (Read et al. 2013) (and see PhycoCosm; the Algal Genomics Resource at this URL: https://mycocosm.jgi.doe.gov/Emihu1/Emihu1.home.html.

Emiliania huxleyi is the most abundant coccolithophore species in the Atlantic Ocean, but it is not the only one. Umbellosphaera irregularis was the next most abundant species, particularly in surface waters of the tropics. Gephyrocapsa oceanica was observed at lower frequencies in both surface and mid-depth samples of the tropics and subtropics but was relatively cosmopolitan, though patchily distributed. Discosphaera tubifera, was more commonly seen in surface samples of the subtropics and in only a few cases in the waters of the deep chlorophyll maximum (DCM). In fact, diversity and species richness of coccolithophore cells was usually greater in surface populations than in the deep DCM. (Balch et al., 2019). The DCM is a subsurface layer, often located tens of metres below the surface, that is enriched in chlorophylla. It forms near the nutricline and the bottom of the photic zone. Growth of phytoplankton in the 
DCM is limited by both nutrient and light availability and the location and formation of the DCM also depends on the season. The DCM cannot be observed using satellite- based remote sensing methods (Fig. 1)(Balch, 2018; Moore et al., 2012). Estimates of primary productivity are often made using such remote sensing, which they obviously underestimate as they cannot detect the deepwater biomass.

At the surface, the upper photic zone is low in nutrient concentrations but high in light intensity and light penetration, and usually higher in temperature. The lower photic zone is high in nutrient concentration but low in light intensity because of low penetration through the overlying water, and relatively cool (Jordan \& Chamberlain, 1997). The abundance of deep-dwelling coccolithophore species is greatly influenced by nutricline and thermocline depths; increasing in abundance when the nutricline and thermocline are deep and decreasing when they are shallow (Kinkel et al., 2000; Boeckel et al., 2006).

Balch et al. (2019) reported the lowest concentrations of coccolithophores in equatorial waters; the highest concentrations of cells and coccoliths were associated with temperate, sub-polar conditions. Coccolithophore species commonly found in deeper waters were: Calciosolenia murrayi (usually found at 40 to $100 \mathrm{~m}$ but also observed in several surface samples), Florisphaera profunda (at 50 to $200 \mathrm{~m}$ ), Michaelsarsia adriaticus (in surface samples, otherwise seen between 50 to $130 \mathrm{~m}$ ), Rhabdosphaera clavigera (also found in surface samples and otherwise between 40 to $200 \mathrm{~m}$ ) and Umbellosphaera foliosa (at 50 to $200 \mathrm{~m}$ ). Calcifier species in deeper waters are likely to be especially important for carbonate production at these depths. Although detached coccoliths were distributed to depths of about $300 \mathrm{~m}$, coccolithophore cell concentrations in the subtropics were highest at less than $200 \mathrm{~m}$ depth in the South Atlantic and less than $100 \mathrm{~m}$ in the North Atlantic.

Living coccolithophores are also distributed widely in the North and South Pacific (Okada \& Susumu, 1973); indeed, they occur in all large bodies of water, such as the Mediterranean Sea, and in all oceans, including the Southern Ocean, from tropical to polar regions (Thierstein \& Young, 2004; Winter \& Siesser, 2006; Winter et al., 2006; Saavedra-Pellitero et al., 2014; Foissner, 2005; Chang \& Northcote, 2016; Menschel et al., 2016; Balch, 2018).

It has been demonstrated in laboratory experiments that the process of calcification is an important physiological trait for coccolithophores (Walker et al., 2018). Coccolith production is an intracellular process and has been enabled by modifications to cell ultrastructure and metabolism; surveyed by Taylor et al. (2017). “... In addition to calcification, which appears to have evolved with a diverse range of functions, several other remarkable features that likely underpin the ecological and evolutionary success of coccolithophores ... include complex and varied life cycle strategies related to abiotic and biotic interactions as well as a range of novel metabolic pathways and nutritional strategies ..." (Taylor et al., 2017).

Though the benefits of calcification can be species specific there are some common features. In particular, production of coccoliths requires uptake of dissolved bicarbonate and calcium.

Calcium carbonate and carbon dioxide are produced from calcium and bicarbonate ions by the following chemical reaction:

$$
\mathrm{Ca}^{2+}+2 \mathrm{HCO}_{3}^{-} \rightleftharpoons \mathrm{CaCO}_{3}+\mathrm{CO}_{2}+\mathrm{H}_{2} \mathrm{O}
$$

(Mackinder et al., 2010; Mejia, 2011; Monteiro et al., 2016). 
It is important here to emphasise the Kantian philosophy that the end of the process has more value in itself than the means to achieve it. The calcification reaction releases $\mathrm{CO}_{2}$, as is shown in the reaction scheme above. This released $\mathrm{CO}_{2}$ will be fixed in photosynthesis. All of these processes require energy and that energy is supplied by respiration, which returns $\mathrm{CO}_{2}$ to the atmosphere. So, the means by which the calcification occurs involves release of $\mathrm{CO}_{2}$ to the atmosphere. However, the end of the process is that the bicarbonate ion that is converted to $\mathrm{CaCO}_{3}$ is now permanently removed from the atmosphere. When the cell dies, or the coccolith is shed, the crystalline $\mathrm{CaCO}_{3}$ will eventually sediment to the seafloor. In the fullness of time, the sediment will become a layer of limestone and will remain as such until subducted into the Earth's mantle, through which the $\mathrm{CO}_{2}$ will be vented eventually as volcanic gas.

Coccolithophores have been major calcium carbonate producers in the world's oceans since the mid-Mesozoic era (Fig. 3).

Increases in $\mathrm{Ca}^{2+}$ concentrations at the Precambrian/Cambrian boundary has been related to the evolution of calcification in protists and invertebrates, linking formation of $\mathrm{CaCO}_{3}$ to the need to detoxify excess calcium. It is argued that $\mathrm{Ca}^{2+}$ concentrations during the Precambrian era were a crucial promoter of the major steps in the evolution of early life such as photosynthesis, eukaryogenesis, multicellularity, origin of metazoans, etc; all of which require close homeostatic control over intracellular $\mathrm{Ca}^{2+}$ levels. Elevated seawater $\mathrm{Ca}^{2+}$ concentrations in the Cretaceous and Jurassic created a need to detoxify extracellular $\mathrm{Ca}^{2+}$ to avoid intracellular precipitation of phosphate ions and maintain cellular calcium homeostasis (Simkiss, 1977; Raven \& Crawfurd, 2012; Kazmierczak et al., 2013; Müller et al., 2015; Müller, 2019). Consequently, evolutionary selection towards a mechanism to achieve the biochemical benefits of intracellular calcium fixation into the biological inert form of $\mathrm{CaCO}_{3}$ also removed from the water and atmosphere the metabolic waste product and volcanic gas, $\mathrm{CO}_{2}$. Coccolith fossils dating back to the Palaeocene-Eocene Thermal Maximum of 55 million years ago (labelled PETM in Fig. 3) are particularly interesting because this period is thought to correspond most directly to the current levels of $\mathrm{CO}_{2}$ in the oceans (Lloyd et al., 2011; Self-Trail et al., 2012).

The relevance of this historical diversion is that it explains why, in today's oceans both calcification and primary production by coccolithophores are significantly increased by elevated $\mathrm{CO}_{2}$ partial pressures, even though this might be at variance with current simulation models (Krumhardt et al., 2019). Coccolithophore calcification accounts for about a third of the total marine $\mathrm{CaCO}_{3}$ production of today's oceans. Evidence from the deep ocean indicates that over the past 220 years there has been a $40 \%$ increase in coccolith mass in the deep sea sediments (Iglesias-Rodriguez et al., 2008). Clearly, the coccolithophores have already reacted to the anthropogenic rise in atmospheric $\mathrm{CO}_{2}$ partial pressures by doing what they have done before: detoxifying their environment. The difference is, this time they are detoxifying atmospheric $\mathrm{CO}_{2}$.

\section{Why coccolithophores could be good for us and our planet}

Overall, coccolithophores exhibit characteristics that, if the fossil record is anything to go by, enable them to be a more effective and more dramatic engineer of this planet and its atmosphere than Homo sapiens. Of course, there is a difference in the timescale. $H$. sapiens makes things (good and bad) happen in a few years or decades; coccolithophore climate engineering occupies tens of millions of years. One way of looking at this is that these algae have a much longer track record in the climate engineering field than us. Maybe we should get together to do something about today's atmosphere. 
Much of the more recent literature on coccoliths has expressed concern about the effects of climate change and ocean acidification. Fox et al. (2020), for example, compared historic plankton collections made in 1872 to 1876 with those made in 2009 to 2016 to quantify the effect of acidification on planktonic calcifying organisms. A small proportion of the readily available literature even hints at the possibility of using coccolithophore algae for industrial purposes, and in some cases to sequester atmospheric $\mathrm{CO}_{2}$. Jakob et al. (2018) describe the successful development of a batch culture process (see below) suitable for the production of coccoliths of Emiliania huxleyi for industrial process developments in the many areas of industry (the cement industry, and potable water filtration, among many others) that depend on chemical reactions at the calcite-water-interface (Heberling et al. 2014). Currently, most industrial calcite $\left(\mathrm{CaCO}_{3}\right)$ is made by crushing mined limestone. Ultrafine synthetic calcite is produced by bubbling $\mathrm{CO}_{2}$ into 'lime milk' (an aqueous solution of calcium hydroxide), when nanometre scale calcite particles precipitate. Jakob et al. (2017) demonstrate that coccoliths of Emiliania huxleyi are likely to be of value as industrial calcite particles. Skeffington \& Scheffel (2018) go further by illustrating how coccoliths might be used as component parts of nanodevices (Figs 4 \& 5). Coccolith calcite can be modified by the incorporation of metal ions or adsorption of enzymes to the surface, but Skeffington \& Scheffel (2018) speculate that genetic modification of coccolithophores may permit the production of coccoliths with customised architectures and surface properties.

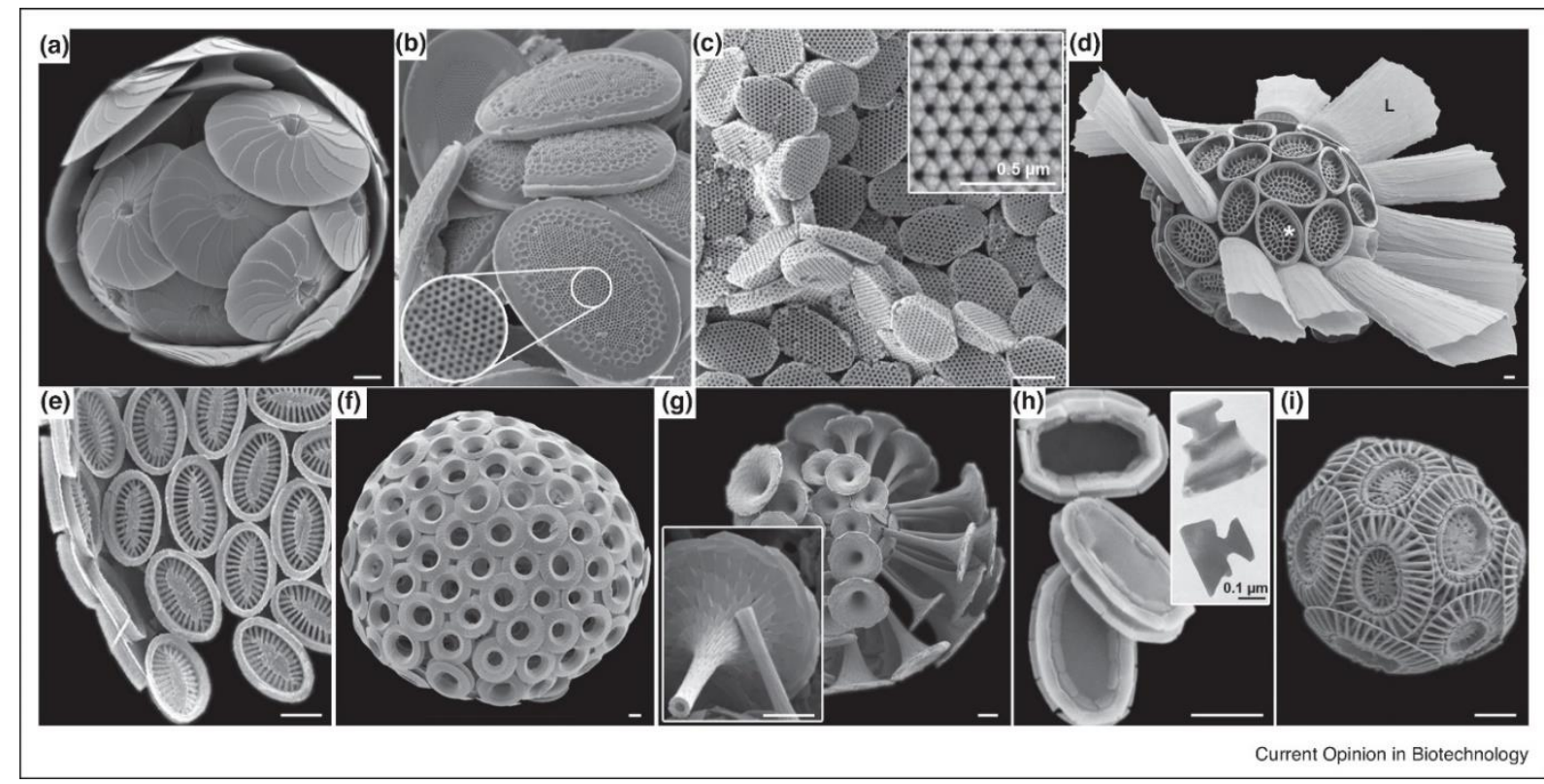

Fig. 4. Coccoliths for nanodevices. Electron micrographs showing the coccoliths of (a) Calcidiscus leptoporus subsp. leptoporus, (b) Pontosphaera japonica, (c) Calyptrolithophora papilifera, (d) Scyphosphaera porosa, (e) Michaelsarsia elegans, (f) Umbilicosphaera sibogae, (g) Discosphaera tubifera, (h) Pleurochrysis carterae, and (i) Emiliania huxleyi. Inset in c shows the hexagonal array packing of the simple-shaped crystallites in these holococcoliths. S. porosa (d) produces dimorphic coccospheres with vase-like 'lapodoliths' ( $\mathrm{L}$ ) and oval casserole-like body coccoliths ${ }^{*}$ ). Inset in g shows the narrow end of the trumpet-like spine which is hollow. Inset in h shows high-magnification image of the complex-shaped calcite crystals of which these coccoliths are composed. Scale bars: $1 \mu \mathrm{m}$. Images a-g by Jeremy Young, University College London, London, UK. From Skeffington \& Scheffel (2018) under a Creative Commons license (CC BY-NC-ND 4.0). 
For carbon sequestration, Jiao et al. (2010) detail the role of ocean-dwelling microorganisms in the generation of a pool of long-lived carbon, using a new concept they call the microbial carbon pump. They set out one hypothetical scenario as: “... the concurrent elevation of $\mathrm{pCO}_{2}$ and ocean temperature could increase microbial activity, channelling a greater fraction of the fixed carbon into recalcitrant dissolved organic matter ...".

Perrin et al. (2016) used light- and nutrient-limited batch photobioreactors to simulate conditions in the lower photic zone and study the physiological of Emiliania huxleyi in the oligotrophic gyres of the South Pacific. They were able to reproduce the in situ conditions of light and nutrient (nitrate and phosphate) limitation, showing that $E$. huxleyi growth in that zone is probably limited by availability of light and nitrate. Another example dealing specifically with prospects for carbon sequestration is the project AlgaCO2 (entitled: Industrial cultivation of microalgae as a green strategy for atmospheric $\mathrm{CO}_{2}$ sequestration) a research programme of the Portuguese Marine And Environmental Sciences Centre (MARE) funded by Fundação para a Ciência e a Tecnologia (FCT), which is the Portuguese national funding agency for science, research and technology [https://www.mare-centre.pt/en/proj/algaco2].

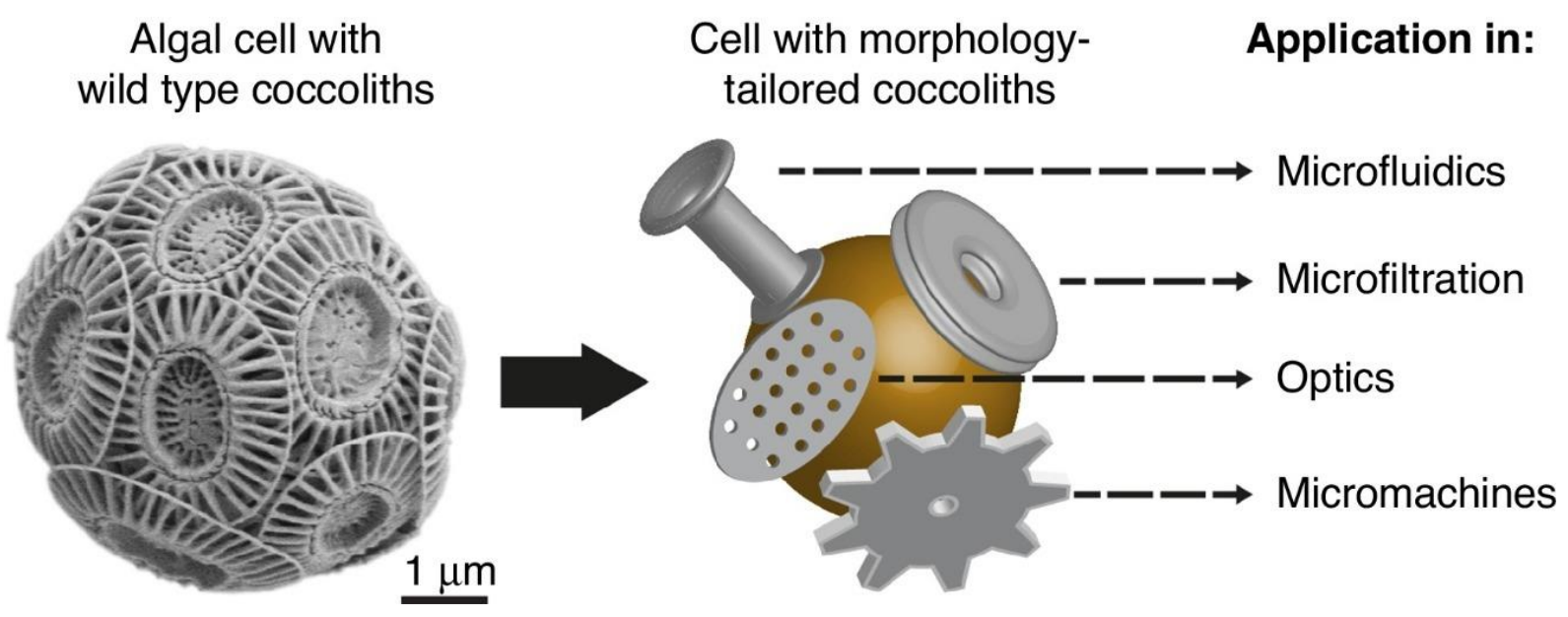

Fig. 5. Cartoon diagram showing the potential applications of coccoliths that might be produced by genetic modification of coccolithophores aimed at creating coccoliths with customised architectures and surface properties. From Skeffington \& Scheffel (2018) under a Creative Commons license (CC BY-NCND 4.0).

Vicente et al. (2019), who are researchers in this AlgaCO2 Programme, state that because microalgae "... remove $\mathrm{CO}_{2}$ from the atmosphere through photosynthesis, their efficient industrial production may represent a sustainable technology for carbon sequestration ..." They identify coccolithophores as useful candidates among the phytoplankton because their calcite coccoliths have many potential uses in nanotechnology (Jakob et al. 2017, 2018; Skeffington \& Scheffel, 2018) (Figs 4 \& 5). Industrial cultivation of coccolithophores, on which all of these potential uses depend, will be explored in the next section.

\section{Coccolithophore cultivation}

Any of the interventions just mentioned are likely to require in vitro cultivation of coccolithophores as starter cultures/inocula. The laboratory culture of marine planktonic organisms is not challenging and was first reviewed by Allen \& Nelson (1910), and there are many insights that are still worth reading in this publication despite its more than 100-year age. 
Guillard, 1975 published a collection of “... relatively simple and reliable methods for the culture of marine phytoplankton species useful for feeding marine invertebrates..." and applied the methods for production "... of sterile cultures of considerable density in volumes up to 18 litres , in commercially available 5 gallon borosilicate glass carboys (Siegelman \& Guillard, 1971).

Keller et al. (1987) described a seawater-based medium which was found suitable for a wide range of phytoplankton, giving its important aspects as the addition of selenium, the inclusion of both nitrate and ammonium, an increased level of chelation and a moderate level of $\mathrm{pH}$ buffering. A more recent review of laboratory culture specifically of coccolithophores was published by Probert \& Houdan, (2004). They point out that laboratory culture experiments have focused on two easily cultured species, Emiliania huxleyi and Pleurochrysis carterae, and there is a lack of comparative data for culture of other coccolithophore species, especially those from oligotrophic oceanic habitats. Nevertheless, they suggest ways of culturing these species, such as reducing concentrations of macro- and micro-nutrients in culture media, and the possible use of organic nutrients in place of mineral nutrients. More general guidance can be found in Lavens \& Sorgeloos (1996), Helm et al. (2004), Rincon et al. (2017) and Jerney \& Spilling (2018).

\section{Large-scale cultivation of coccolithophores}

Vicente et al. (2019) isolated coccolithophores from Portuguese coastal waters (strains of Emiliania huxleyi and Coccolithus braarudi) for cultivation under laboratory conditions, using batch cultures and a standard laboratory medium ('Guillard's F/2' (Guillard \& Ryther, 1962; Guillard, 1975); a commercially available Marine Water Enrichment Solution) and an industrial medium to mimic conditions of an industrial unit.

There is a considerable industry devoted to large scale production of microalgae, and there is no shortage of knowhow because the commercial farming of microalgae goes back to the middle of the twentieth century (Borowitzka, 2013). Kurano \& Miyachi (2004) pointed out that microalgal photosynthesis is efficient enough to fix $\mathrm{CO}_{2}$ from the atmosphere and from industrially discharged gases, representing a possible future alternative for $\mathrm{CO}_{2}$ reduction in both [and see [https://www.powermag.com/breakthrough-carbon-capturing-algae-project/].

According to Borowitzka \& Moheimani (2013): “... Microalgae are currently probably the most studied potential source of biofuels, and in the US alone there are some 30+ companies working in the area and total investment in R\&D is in excess of several billion \$US worldwide ... One of the key attractions of microalgae is the high lipid content of some species ..., and the production ... of biodiesel from these ...".

Biodiesel is prepared from algal lipids by esterifying free fatty acids or trans-esterifying triacylglycerol fatty acids by reacting them with an alcohol, usually methanol or ethanol. Compared to oilseed crops of terrestrial plants, autotrophic microalgae are capable of achieving very high conversion efficiencies of solar energy into biomass and oil. But as well as their high lipid and/or sugar content, another feature of microalgae that makes them attractive sources of renewable biofuels ('green diesel') is that they can be grown using saline water on land that is not suitable for agriculture (Borowitzka, 2010; Torrey, 2010; Davis et al., 2011; Ullah et al., 2014). Davis et al. (2011) claim that “... It is well-established that microalgal-derived biofuels have the potential to make a significant contribution to the US fuel market...". And, of course, every litre of biodiesel that is used saves the use of a litre of fossil fuel; merely cycling present day $\mathrm{CO}_{2}$ through the atmosphere rather than adding long fossilised $\mathrm{CO}_{2}$ to our present day atmosphere. 
Another example of a successful microalgal industry is the product known as Spirulina, which is actually the dried biomass of a photosynthetic bacterium (cyanobacterium) Arthrospira platensis, which was once classified in the genus Spirulina, which is maintained as the common name for the commercial product. Spirulina is protein-rich and used widely as a niche health food. Dried Spirulina typically contains 5\% water, $24 \%$ carbohydrates, $8 \%$ fat, and about $60 \%$ protein, together with numerous vitamins and minerals. It has the distinction of being advocated by both NASA and ESA (the European Space Agency) for cultivation on long-term space missions as food for astronauts travelling to Mars. As it requires less land and water than farm animals to produce and has a much lesser impact on the carbon balance of the environment than farm animals and their demands for feed, this nutritious protein and energy food is gaining wide use on Earth to supplement human diets and as an alternative feed for animals in agriculture and aquaculture (Sachdeva et al., 2004; Tuomisto, 2010; Alexander et al., 2017). Spirulina is also rich in bioactive substances that have bio-modulatory and immuno-modulatory activities (Khan et al., 2005), and although the evidence is not yet sufficient to endorse Spirulina supplement as treatment for any human disorder, some of those bioactive substances are potent antioxidant and anti-proliferative agents and have been shown to decrease the proliferation of experimental pancreatic cancer (Koníčková et al., 2014).

As a potential 'superfood' there is plenty of advice on the Internet for 'home grown' cultivation of Spirulina. An example is the YouTube video Smart Microfarms - Algae Growing Systems for Home \& Backyard [https://youtu.be/XZWONpvxTH8]; and compare this with the commercial production process which is shown at this URL: http://www.aurospirul.com/productionprocess.html]. Much more basic methods of cultivating home-grown algae aimed at aquarists is shown at: https://www.wikihow.com/Grow-Algae and https://bitesizebio.com/27998/open-closedtwo-ways-grow-algae/; and you can buy your Spirulina starter cultures from Amazon [https://www.amazon.co.uk/HealthAlgae-Spirulina-platensis-living-culture/dp/B07F93L1C7].

On the commercial scale there are a number of production technologies in use and under development that fall into two basic types:

- Open ponds (raceways).

- Closed, illuminated, 'fermentation' tanks, usually called photobioreactor (PBR) systems.

The common feature of all technologies is maximisation of algal growth for production of the desired industrial product(s) (fuel, chemicals/pharmaceuticals, biomass or, in our case, $\mathrm{CaCO}_{3}$ ). Therefore, apart from the intended end-product, the most suitable approach to employ depends on location, available work force and, of course, economics and finance [http://biomassmagazine.com/]

Davis et al. (2011) established the baseline economics for using microalgae to produce biofuels using either open pond cultivation or closed photobioreactor (PBR) systems. They found that to achieve a $10 \%$ return on investment the cost of production of diesel (including hydrogenation of algal oils to produce a 'green diesel' blend stock) was $\$ 9.84$ gallon $^{-1}$ for open ponds and $\$ 20.53$ gallon $^{-1}$ of diesel. Which makes the open pond approach the one to use, providing the location and othere negative factors permit.

Open-culture systems rely on natural light for illumination and are inexpensive to install and run. They may be based on natural small ponds, lakes or lagoons; or be entirely artificial ponds, containers or tanks. The most popular open pond system is the artificial raceway pond in which nutrients, algae, and water flow along a circular path, the circulation being maintained by a paddlewheel (Fig. 6). 
Ponds vary in size from $0.5 \mathrm{~m}^{2}$ to $100 \mathrm{~m}^{2}$; a single paddlewheel can provide sufficient mixing for a 5 ha $\left(50,000 \mathrm{~m}^{2}\right)$ cultivation area. Being outdoor facilities, open-culture systems suffer from several outdoor-related problems:

- $\quad$ As the cultures are usually not axenic, photosynthetic contaminants (algal, cyanobacterial) can out-compete the desired species.

- Contaminating algal predators (and that grouping might include flocks of water birds!) can graze the culture, causing significant crop losses.

- Weather conditions can cause evaporative losses if too warm, while rainfall dilutes the growth medium and reduces light intensity; all of which make proper control of nutrients, light intensity, and $\mathrm{CO}_{2}$ levels challenging.

- Uncontrolled changes in water temperatures can inhibit high production; for this reason, geographical locations where temperatures range higher than $15^{\circ} \mathrm{C}$ are favoured for openculture systems.

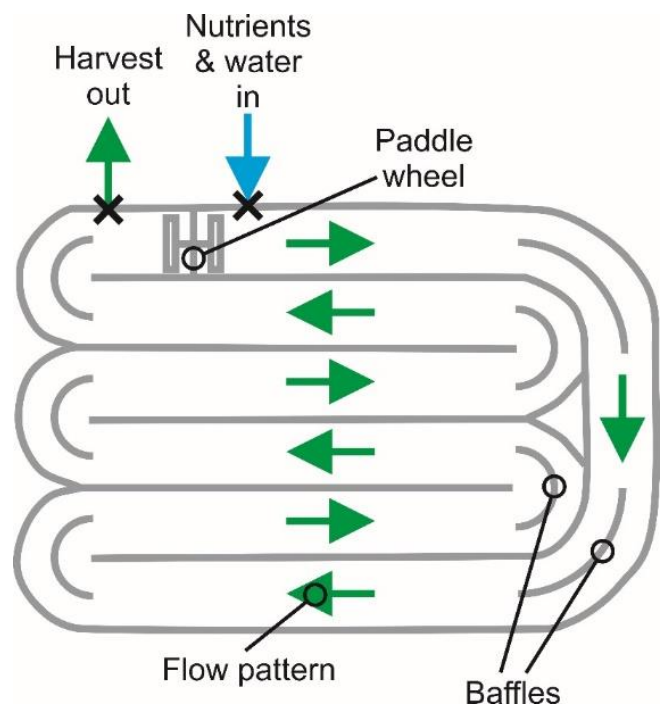

Fig. 6. Diagrammatic plan view of a raceway pond and its water circulation (redrawn after Xu et al., 2009).

Closed photobioreactors, in contrast, allow control of all these features. But in their case the technical challenge starts with making the bioreactors axenic, and then proceeds to providing mechanisms to control temperature, nutrients, gas exchange and adequate mixing, just like any other fermenter-style bioreactor. By their very nature, closed reactors allow better and more immediate control of culture conditions than open systems.

Unfortunately, they are also usually more expensive to install, but the biggest design challenge is to provide illumination for the photosynthetic microorganisms, generally using fluorescent or LED lighting rigs. Photobioreactors used for cultivation of microalgae vary in their architecture and include flat-plate, horizontal, inclined or vertical, and serpentine tubular airlift photobioreactors (Fig. 7), and biofilm reactors, where the algal cells are immobilised onto surfaces within the reactor (Qureshi et al. 2005; Ugwu et al., 2008; Xu et al., 2009; Ketheesan \& Nirmalakhandan, 2012; Narala et al., 2016; Acién et al., 2017; Rincon et al., 2017).

$\mathrm{Xu}$ et al. (2009) published comparisons of the characteristics of open and closed systems, shown in Table 1. They state that "... In view of potential applications, development of a more controllable, economical, and efficient closed culturing system is needed. Further developments 
still depend on continued research in the design of photobioreactors and break-throughs in microalgal culturing technologies...".

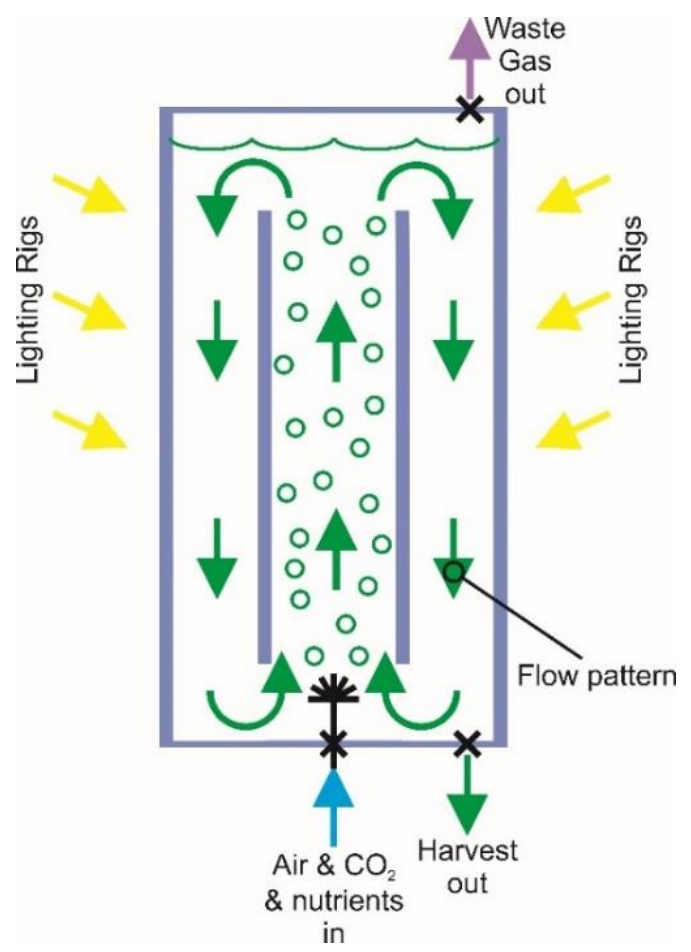

Fig. 7. Schematic of an airlift photobioreactor (redrawn after Xu et al., 2009).

Table 2. A comparison of the levels of risk of open and closed systems for microalgae.

\begin{tabular}{|l|c|c|}
\hline Characteristic & Open systems & Closed systems \\
\hline Contamination risk & High & Low \\
\hline $\mathrm{CO}_{2}$ losses & High & Low \\
\hline Evaporative losses & High & Low \\
\hline Light use efficiency & Poor & Excellent \\
\hline Area/volume ratio & Low \\
\hline Area required & High & Low \\
\hline Process control & Difficult & Easy \\
\hline Biomass productivities & Low & High \\
\hline Investment costs & Low & High \\
\hline Operation costs & Low & High \\
\hline Harvesting costs & High & Relatively low \\
\hline Scale-up & Easy & Difficult \\
\hline From Xu et al., 2009. & & \\
\hline
\end{tabular}


Narala et al. (2016) developed a two-stage hybrid cultivation system using a marine species of the green microalga Tetraselmis (Chlorophyta), which may have future use in biofuel production. The hybrid system gave significantly higher yields of algal lipids than either single stage system; it combined an initial exponential biomass production in air lift photobioreactors, with a second high-lipid induction phase in nutrient depleted open raceway ponds. Nutrients were added only to the closed photobioreactors, greatly improving biomass yields; while the open raceway ponds had turnovers of only a few days, which reduced crop losses due to microalgal grazers.

There remain a few particular problems related to the biology of microalgae. One is the matter of the fragility of microalgal cells which can have adverse effects on production in closed photobioreactors. Cell damage results in a reduced growth rate, but the cause is the hydrodynamic stress resulting from the vigorous pumping and mixing needed to ensure turbulent flow of the culture, which is necessary to optimise the light regime. Factors influencing hydrodynamic stress (bioreactor geometry, type of pump, and morphology and physiology of algal cells) are discussed by Gudin \& Chaumont (1991).

Another problem, applying specifically to the diploid phase of the life cycle of coccolithophores, particularly Emiliania huxleyi, is their susceptibility to a lytic infection caused by giant DNAcontaining viruses, known as E. huxleyi viruses or EhVs. EhVs infect the coccosphere and induce programmed cell death of the diploid algal cell (Vardi et al., 2012).

Long-term cultivation of the coccolithophore Pleurochrysis carterae in outdoor raceway ponds has been reported by Moheimani \& Borowitzka (2006). The experiments on this calcifying marine haptophyte alga were carried out because of the likely impact of their blooms in nature on the carbon cycle. The coccolithophore was grown "... semi-continuously in paddlewheeldriven outdoor raceway ponds over a period of 13 months in Perth, Western Australia." The biomass yield achieved was $0.19 \mathrm{~g} \mathrm{l}^{-1} \mathrm{~d}^{-1}$ (dry weight), of which cell lipid amounted to $33 \%$ and $\mathrm{CaCO}_{3}$ to $10 \%$.

Overall, aggregate productivity of $P$. carterae biomass averaged an annual total of 60 tonnes $\mathrm{ha}^{-1} \mathrm{y}^{-1}$, representing 21.9 tonnes ha $\mathrm{h}^{-1} \mathrm{y}^{-1}$ total lipid and 5.5 tonnes ha ${ }^{-1} \mathrm{y}^{-1}$ calcium carbonate. On a molar mass basis, carbon represents $12 \%$ of the mass of calcium carbonate; consequently, each hectare $\left(10,000 \mathrm{~m}^{2}\right)$ of raceway pond devoted to cultivation of the coccolithophore Pleurochrysis carterae removes 0.66 tonnes of carbon from the atmosphere each year.

The Intergovernmental Panel on Climate Change Special Report of 2018 (IPCC, 2018) suggested that an increase of 1 billion hectares of forest will be necessary to limit global warming to $1.5^{\circ} \mathrm{C}$ by 2050 . There seems to be wide acceptance that we should contemplate that remedy, even though it is becoming increasingly clear that planting trees for carbon capture is, at best, only a temporary sequestration (Moore et al., 2021). But before that endeavour becomes a done-deal, should we not at least consider creating 1 billion hectares of coccolithophore bloom in the open ocean and/or raceway ponds in appropriate locations? That amount of coccolithophore cultivation could permanently remove 0.66 billion tonnes of carbon from the atmosphere each year, which is equivalent to about $7 \%$ of our annual global carbon emissions from fossil fuel.

The area of the Pacific Ocean is 16 billion hectares; there's probably enough space there to generate coccolithophore algal blooms that would make a serious dent in the atmosphere's carbon load. If anybody could be bothered to make it happen. 


\section{What we might do}

In the bullet points below are suggested the actions that could be taken to exploit fully the potential for cultivation of coccolithophore algae on such large scales that (a) their carbon sequestration will contribute to detoxifying our present day atmosphere; (b) they will provide today's $\mathrm{CaCO}_{3}$ that will free the cement industry from its use of long-fossilised $\mathrm{CO}_{2}$; (c) their cellular biomass will provide lipids and biofuels to replace fossil fuel usage, as well as other bioactive substances with potential pharmaceutical uses; and (d) they will provide tailor-made coccoliths for developments in the nanotechnology industries.

All of these features are currently known as ecosystem services, which are defined as "... the benefits provided by ecosystems that contribute to making human life both possible and worth living ..." [http://uknea.unep-wcmc.org/Home/tabid/38/Default.aspx]. It may be unlikely that any one installation could provide all of these services. For example, a large terrace of raceway ponds intended to supply crystalline $\mathrm{CaCO}_{3}$ to the cement industry is unlikely to be able to provide the nanoscale engineering needed by nanotechnology industries. Nevertheless, all of these services are available from a human-enhanced coccolithophore ecosystem; we just need to find the human get-up-and-go to DO it.

There is one other ecosystem service that very large-scale deployment of coccolithophores in the oceanic high seas could provide, which is to contribute to cloud brightening in the expectation that this would produce an atmospheric cooling effect by reflecting solar radiation back into space before it reaches the Earth's surface which it would otherwise warm and reradiate infrared that greenhouse gases then trap in the atmosphere. This has been suggested as a geoengineering technique that might use sub-micrometre sea water particles injected into the atmosphere in sufficient number to enhance cloud droplet formation (Latham et al., 2012), although "... altering the Earth's radiative energy budget ..." may not be an entirely reliable step (Lawrence et al., 2018). However, I remind you of the paragraph above describing how algal blooms produce the volatile gas dimethyl sulfide (DMS), which itself promotes cloud formation (Keller, 1989; Alcolombri et al., 2015). So, here is potential ecosystem service (e): promote formation of clouds that reflect solar radiation, which cools the ocean by altering the radiative energy budget, consequently, reducing coccolithophore activity, thereby reducing levels of DMS; in a classic, self-regulating feedback loop.

The actions I suggest we should take to exploit the potential of coccolithophore algal cultivation and deployment are as follows.

- A tropical agriculture solution, using ponds, raceways or terraces (Schwab et al., 1996; Baryła \& Pierzgalski, 2008) on tropical (desert?) coastlines continuously filled with ocean water (pumped by solar-energy), and continuously trickling downhill into successively lower terraces during the day and left to settle at night. The sludge of insoluble crystals of calcium carbonate being dredged from the lowest terraces, providing a renewable feedstock of quicklime for cement production in place of the fossiliferous limestone that is currently used. Our way of life uses a lot of cement and cement production is the source of about $8 \%$ of the world's $\mathrm{CO}_{2}$ emissions (Lehne \& Preston, 2018).

- A biotechnology solution, cultivating coccolithophore algae in large industrial LEDilluminated fermenters (photobioreactors) operating in continuous-culture mode (powered by renewable energy sources), which, again, could yield a continuous harvest of insoluble crystals of calcium carbonate, providing a renewable feedstock for cement production to replace the fossil limestone that is currently used to make quicklime. Additionally, the closer control and greater sensitivity of closed photobioreactors would allow arrays of such 
devices to be used for the development, using gene-editing technology, and production of 'designer coccoliths' for use in nanodevices.

A high seas solution, by creating an artificial upwelling of nutrient-rich waters using a Perpetual Salt Fountain as advocated by Heilweck \& Moore (2021) "... This can be made to work where you have a warm and salty water mass above a colder and fresher one. The technique is to insert a vertical duct between these two layers, and then pump it out until the pipe is filled with the deep water. You can then stop pumping. The upflow from the lower layer will last perpetually, without any other external energy expenditure ... it is the density difference caused by the salinity difference that drives the upward flow...". This could be done either using the sea mount installations described by Heilweck \& Moore (2021) or by the use of floating processing plants or 'factory ships' [https://en.wikipedia.org/wiki/Factory ship]. These would be similar to those used to process oceanic capture fishery catches but these would instead have 'factories' capable of cultivating both suitable species of coccolithophores and suitable species of bivalve molluscs in aquaculture nurseries onboard ship during their open ocean cruises. The ships would also be able to produce biodegradable floatation devices already spawned with fixed juvenile bivalve molluscs that could be released into the ocean currents and ocean gyres far away from shipping lanes and commerce routes. The ships would also be equipped to create Perpetual Salt Fountains (Heilweck \& Moore, 2021) to bring deep water nutrient streams closer to the surface into which coccolithophore algae, cultivated in photobioreactors onboard, could be released to create and maintain blooms of coccolithophores in the oceanic high seas.

\section{References}

Acién F.G., Molina E., Reis A., Torzillo G., Zittelli G.C., Sepúlveda C. \& Masojídek J. 2017. Photobioreactors for the production of microalgae. Pp. 1-44 in Microalgae-Based Biofuels and Bioproducts, Woodhead Publishing Series in Energy, (ed C. Gonzalez-Fernandez \& R. Muñoz). ISBN 9780081010235. DOI: https://doi.org/10.1016/B978-0-08-101023-5.00001-7.

Alcolombri U., Ben-Dor S., Feldmesser E., Levin Y., Tawfik D.S., Vardi A. 2015. Identification of the algal dimethyl sulfide-releasing enzyme: a missing link in the marine sulfur cycle. Science. 348: 1466-1469. DOI: https://doi.org/10.1126/science.aab1586.

Alexander P., Brown C., Arneth A., Dias C., Finnigan J., Moran D. \& Rounsevell M.D.A. 2017. Could consumption of insects, cultured meat or imitation meat reduce global agricultural land use? Global Food Security. 15: 22-32. DOI: https://doi.org/10.1016/i.gfs.2017.04.001.

Allen E.J. \& Nelson E.W. 1910. On the artificial culture of marine plankton organisms. Journal of the Marine Biological Association of the United Kingdom. 8: 421-474. DOI: https://doi.org/10.1017/S0025315400073690.

Balch W. M. 2018. The ecology, biogeochemistry, and optical properties of coccolithophores. Annual Review of Marine Science. 10, 71-98. DOI: https://doi.org/10.1146/annurev-marine121916-063319.

Balch W.M., Bowler B.C., Drapeau D.T., Lubelczyk L.C., Lyczkowski E., Mitchell C. \& Wyeth A. 2019. Coccolithophore distributions of the North and South Atlantic Ocean. Deep Sea Research Part l: Oceanographic Research Papers. 151: article 103066. DOI: https://doi.org/10.1016/j.dsr.2019.06.012. 
Baryła A. \& Pierzgalski E. 2008. Ridged terraces - functions, construction and use. Journal of Environmental Engineering and Landscape Management. 16: 1-6. DOI: https://doi.org/10.3846/1648-6897.2008.16.104-109.

Bentaleb I., Grimalt J.O., Vidussi F., Marty J.-C., Martin V., Denis M., Hatté C.\& Fontugne M. 1999. The $\mathrm{C}_{37}$ alkenone record of seawater temperature during seasonal thermocline stratification. Marine Chemistry. 64: 301-313. DOI: https://doi.org/10.1016\%2FS03044203\%2898\%2900079-6.

Blanco-Ameijeiras S., Lebrato M., Stoll H.M., Iglesias-Rodriguez D., Müller M.N., MéndezVicente A. \& Oschlies A. 2016. Phenotypic variability in the coccolithophore Emiliania huxleyi. PLoS One. 11: article e0157697. DOI: https://doi.org/10.1371/journal.pone.0157697.

Boeckel B., Baumann K.-H., Henrich R. \& Kinkel H. 2006. Coccolith distribution patterns in South Atlantic and Southern Ocean surface sediments in relation to environmental gradients. Deep-Sea Research Part I: Oceanographic Research Papers. 53: 1073-1099. DOI: https://doi.org/10.1016\%2Fj.dsr.2005.11.006.

Borowitzka M.A. 2010. Algae oils for biofuels: chemistry, physiology, and production. Pp. 271289. In: Single Cell Oils (Second Edition), (eds Z. Cohen \& C. Ratledge). Urbana, IL, USA: American Oil Chemists Society (AOCS) Press, an imprint of Elsevier Inc. ISBN 9781893997738. DOI: https://doi.org/10.1016/B978-1-893997-73-8.50017-7.

Borowitzka M.A. 2013. Energy from microalgae: a short history. Pp. 1-16. In: Algae for Biofuels and Energy. Developments in Applied Phycology 5, (eds M.A. Borowitzka \& N.R. Moheimani). Dordrecht: Springer Science+Business Media. Pp. 288. ISBN: 9789400754782. DOI: https://doi.org/10.1007/978-94-007-5479-9 1.

Borowitzka M.A. \& Moheimani N.R. (eds). 2013. Algae for Biofuels and Energy. Developments in Applied Phycology. 5, Dordrecht: Springer Science+Business Media. Pp. 288. ISBN: 9789400754782. DOI: https://doi.org/10.1007/978-94-007-5479-9.

Bown P.R., Lees J.A. \& Young J.R. 2004. Calcareous nannoplankton evolution and diversity through time. Pp. 481-508. In: Coccolithophores: From Molecular Processes to Global Impact, (eds H.R. Thierstein \& J.R. Young). Berlin, Heidelberg: Springer. ISBN: 9783540219286. DOI: https://doi.org/10.1007/978-3-662-06278-4 18.

Buitenhuis E.T., Pangerc T., Franklin D.J., Le Quéré C. \& Malin G. 2008. Growth rates of six coccolithophorid strains as a function of temperature. Limnology and Oceanography. 53: 11811185. DOI: https://doi.org/10.4319\%2Flo.2008.53.3.1181.

Chang F.H. \& Northcote L. 2016. Species composition of extant coccolithophores including twenty six new records from the southwest Pacific near New Zealand. Marine Biodiversity Records. 9: article 75. DOI: https://doi.org/10.1186/s41200-016-0077-7.

Chimileski S. \& Kolter R. 2017. Life at the Edge of Sight: a Photographic Exploration of the Microbial World. Cambridge, MA, USA: Harvard University Press. 250 pp. ISBN: 9780674975910. URL: https://www. hup. harvard.edu/catalog. php?isbn=9780674975910\#.

Connor S.A. 2008. Can seashells save the world? Science News in: The Independent, of Wednesday 23 April 2008. URL: https://www.independent.co.uk/news/science/can-seashellssave-the-world-813915.html. 
Davis R., Aden A. \& Pienkos P.T. 2011. Techno-economic analysis of autotrophic microalgae for fuel production. Applied Energy. 88: 3524-3531. DOI: https://doi.org/10.1016/..apenergy.2011.04.018.

de Vargas C., Aubrey M.P., Probert I. \& Young J. 2007. Origin and evolution of coccolithophores: from coastal hunters to oceanic farmers. Chapter 12, pp 251-285. In: Evolution of Primary Producers in the Sea, (eds P.G. Falkowski \& A.H. Knoll). ISBN 9780123705181. Boston: Elsevier. Chapter DOI: https://doi.org/10.1016/B978-0123705181/50013-8. Book DOI: https://doi.org/10.1016/B978-0-12-370518-1.X5000-0.

Egge J.K. \& Aksnes D.L. 1992. Silicate as regulating nutrient in phytoplankton competition. Marine Ecology Progress Series. 83: 281-289. DOI: https://doi.org/10.3354\%2Fmeps083281.

Eikrem W., Medlin L.K., Henderiks J., Rokitta S., Rost B., Probert I., Throndsen J. \& Edvardsen B. 2017. Haptophyta. Pp. 893-953 in: Handbook of the Protists. (eds J. Archibald, A. Simpson \& C. Slamovits). Cham, Switzerland: Springer. ISBN: 9783319281476. DOI: https://doi.org/10.1007/978-3-319-28149-0 38.

Foissner W. 2005. Biogeography and dispersal of micro-organisms: a review emphasizing protists. Acta Protozoologica. 45: 111-136. URL: http://www1. nencki.gov.pl/pdf/ap/ap921.pdf.

Fox L., Stukins S., Hill T. \& Miller C.G. 2020. Quantifying the effect of anthropogenic climate change on calcifying plankton. Scientific Reports. 10: article 1620. DOI: https://doi.org/10.1038/s41598-020-58501-w.

Geisen M., Young J.R., Probert I., Sáez A.G., Baumann K.-H., Sprengel C., Bollmann J., Cros L., de Vargas C. \& Medlin L.K. 2004. Species level variation in coccolithophores. Pp. 327-366 in: Coccolithophores: From Molecular Processes to Global Impact, (eds H.R. Thierstein \& J.R. Young). Berlin, Heidelberg: Springer. ISBN: 9783540219286. DOI: https://doi.org/10.1007/9783-662-06278-4 13.

Gudin C. \& Chaumont D. 1991. Cell fragility - the key problem of microalgae mass production in closed photobioreactors. Bioresource Technology. 38: 145-151. DOI: https://doi.org/10.1016/0960-8524(91)90146-B.

Guillard R.R.L. 1975. Culture of phytoplankton for feeding marine invertebrates. Pp. 26-60, in: Culture of Marine Invertebrate Animals, (eds W.L. Smith \& M.H Chanley). New York, USA: Plenum Press. ISBN: 9781461587163 (2013 softcover reprint of the original). DOI: https://doi.org/10.1007/978-1-4615-8714-9 3.

Guillard R.R.L. \& Ryther J.H. 1962. Studies of marine planktonic diatoms. I. Cyclotella nana Hustedt and Detonula confervacea Cleve. Canadian Journal of Microbiology. 8: 229-239. DOI: https://doi.org/10.1139/m62-029.

Heberling F., Bosbach D., Eckhardt J. D., Fischer U. and 13 others. 2014. Reactivity of the calcite-water-interface, from molecular scale processes to geochemical engineering. Applied Geochemistry. 45, 158-190. DOI: https://doi.org/10.1016/j.apgeochem.2014.03.006.

Heilweck M. \& Moore D. 2021. Saving the Planet with Appropriate Biotechnology: 3. The High Seas Solution/Salvando el planeta con biotecnología apropiada: 3. La solución de alta mar. 
Mexican Journal of Biotechnology. 6(1): 92-128. $\quad$ DOI: https://doi.org/10.29267/mxib.2021.6.1.92.

Helm M.M., Bourne N. \& Lovatelli A. 2004. Hatchery culture of bivalves. A practical manual. Part 3: Hatchery operation: culture of algae. FAO Fisheries Technical Paper. No. 471, pp. 203. Rome: Food and Agriculture Organization of the United Nations. ISBN 9251052247. URL: http://www.fao.org/3/y5720e/y5720e08.htm. PDF: http://aquacultura.org/.

Houdan A., Bonnard A., Fresnel J., Fouchard S., Billard C. \& Probert I. 2004. Toxicity of coastal coccolithophores (Prymnesiophyceae, Haptophyta). Journal of Plankton Research. 26: 875883. DOI: https://doi.org/10.1093/plankt/fbh079.

Iglesias-Rodriguez M.D., Halloran P.R., Rickaby R.E.M., Hall I.R., Colmenero-Hidalgo E., Gittins J.R., Green D.R.H., Tyrrell T., Gibbs S.J., von Dassow P., Rehm E., Armbrust E.V. \& Boessenkool K.P. 2008. Phytoplankton calcification in a high- $\mathrm{CO}_{2}$ world. Science. 320: 336-340. DOI: https://doi.org/10.1126/science.1154122.

IPCC, 2018. Special Report on the Impacts of Global Warming of $1.5{ }^{\circ} \mathrm{C}$ above Pre-Industrial Levels and Related Global Greenhouse Gas Emission Pathways. View this URL: https://www.ipcc.ch/sr15/.

Irie T., Bessho K., Findlay H.S. \& Calosi P. 2010. Increasing costs due to ocean acidification drives phytoplankton to be more heavily calcified: optimal growth strategy of coccolithophores. PLOS ONE. 5: article e13436. DOI: https://doi.org/10.1371/journal.pone.0013436.

Jakob I., Chairopolus M.A., Vučak M, Posten C. \& Teipel U. 2017. Biogenic calcite particles from microalgae - coccoliths as a potential raw material. Engineering in Life Sciences. 17: 605612. DOI: https://doi.org/10.1002/elsc.201600183.

Jakob I., Weggenmann F. \& Posten C. 2018. Cultivation of Emiliania huxleyi for coccolith production. Algal Research. 31: 47-59. DOI: https://doi.org/10.1016/i.algal.2018.01.013.

Jerney J. \& Spilling K. 2018. Large scale cultivation of microalgae: open and closed systems. In: Biofuels from Algae, (ed K.Spilling). Methods in Molecular Biology. 1980: 1-8. DOI: https://doi.org/10.1007/7651 2018130.

Jiao N., Herndl G., Hansell D. Benner R., Kattner G., Wilhelm S.W., Kirchman D.L., Weinbauer M.G., Luo T., Chen F. \& Azam F. 2010. Microbial production of recalcitrant dissolved organic matter: long-term carbon storage in the global ocean. Nature Reviews Microbiology. 8: 593-599. DOI: https://doi.org/10.1038/nrmicro2386.

Jordan R.W. \& Chamberlain A.H.L. 1997. Biodiversity among haptophyte algae. Biodiversity \& Conservation. 6: 131-152. DOI: https://doi.org/10.1023\%2FA\%3A1018383817777.

Kazmierczak J., Kempe S. \& Kremer B. 2013. Calcium in the early evolution of living systems: a biohistorical approach. Current Organic Chemistry. 17: 1738-1750. DOI: https://doi.org/10.2174/13852728113179990081.

Keller M.D. 1989. Dimethyl sulfide production and marine phytoplankton: the importance of species composition and cell size. Biological Oceanography. 6: 375-382. DOI: https://doi.org/10.1080/01965581.1988.10749540. 
Keller M.D., Selvin R.C., Claus W. \& Guillard R.R.L. 1987. Media for the culture of oceanic ultraphytoplankton. Journal of Phycology. 23: 633-638. DOI: https://doi.org/10.1111/1.15298817.1987.tb04217.x.

Ketheesan B. \& Nirmalakhandan N. 2012. Feasibility of microalgal cultivation in a pilot-scale airlift-driven raceway reactor. Bioresource Technology. 108: 196-202. DOI: https://doi.org/10.1016/i.biortech.2011.12.146.

Khan Z., Bhadouria P. \& Bisen P.S. 2005. Nutritional and therapeutic potential of Spirulina. Current Pharmaceutical Biotechnology. 6: 373-379. DOI: https://doi.org/10.2174/138920105774370607.

Kinkel H., Baumann K.-H. \& Čepek M. 2000. Coccolithophores in the equatorial Atlantic Ocean: response to seasonal and Late Quaternary surface water variability. Marine Micropaleontology. 39: 87-112. DOI: https://doi.org/10.1016/S0377-8398(00)00016-5.

Koníčková R., Vaňková K., Vaníková J., Vánová K., Muchová L., and 10 others. 2014. Anticancer effects of blue-green alga Spirulina platensis, a natural source of bilirubin-like tetrapyrrolic compounds. Annals of Hepatology. 13: 273-283. DOI: https://doi.org/10.1016/S1665-2681(19)30891-9.

Krumhardt K.M., Lovenduski N.S., Long M.C., Levy M., Lindsay K., Moore J.K. \& Nissen C. 2019. Coccolithophore growth and calcification in an acidified ocean: insights from community earth system model simulations. Journal of Advances in Modeling Earth Systems. 11: 14181437. DOI: https://doi.org/10.1029/2018MS001483.

Kurano N. \& Miyachi S. 2004. Microalgal studies for the 21st Century. Hydrobiologia. 512: 2732. DOI: https://doi.org/10.1023/B:HYDR.0000020362.58480.ed.

Latham J., Bower K., Choularton T., Coe H., Connolly P., Cooper G. and 19 others. 2012. Marine cloud brightening. Philosophical Transactions of the Royal Society of London A, Mathematical, Physical and Engineering Sciences. 370: 4217-4262. DOI: https://doi.org/10.1098/rsta.2012.0086.

Lavens P. \& Sorgeloos P. 1996. Manual on the production and use of live food for aquaculture. FAO Fisheries Technical Paper, No. 361. Rome: FAO. 306 pp. ISBN 9251039348. URL: http://www.fao.org/3/w3732e/w3732e01.htm. PDF: https://www.researchgate.net/.

Lawrence M.G., Schäfer S., Muri H., Scott V., Oschlies A., Vaughan N.E., Boucher O., Schmidt H., Haywood J. \& Scheffran J. 2018. Evaluating climate geoengineering proposals in the context of the Paris Agreement temperature goals. Nature Communications. 9: article number 3734. DOI: https://doi.org/10.1038/s41467-018-05938-3.

Lehne J. \& Preston F. 2018. Making Concrete Change: Innovation in Low-carbon Cement and Concrete. A Chatham House Report. London: The Royal Institute of International Affairs. ISBN: 9781784132729. Open source URL: https://www.chathamhouse.org/.

Lloyd G.T., Smith A.B. \& Young J.R. 2011. Quantifying the deep-sea rock and fossil record bias using coccolithophores. Geological Society, London, Special Publications. 358: 167-177. DOI: https://doi.org/10.1144/sp358.11. 
Mackinder L., Wheeler G., Schroeder D., Riebesell U. \& Brownlee C. 2010. Molecular mechanisms underlying calcification in coccolithophores. Geomicrobiology Journal. 27: 585595. DOI: https://doi.org/10.1080/01490451003703014.

Mejia R. 2011. Will ion channels help coccolithophores adapt to ocean acidification? PLoS Biology. 9: article e1001087. DOI: https://doi.org/10.1371/journal.pbio.1001087.

Menschel E., González H.E. \& Giesecke R. 2016. Coastal-oceanic distribution gradient of coccolithophores and their role in the carbonate flux of the upwelling system off Concepción, Chile (36 $\left.6^{\circ}\right)$. Journal of Plankton Research. 38: 798-817. DOI: https://doi.org/10.1093/plankt/fbw037SN 0142-7873.

Moheimani N.R. \& Borowitzka M.A. 2006. The long-term culture of the coccolithophore Pleurochrysis carterae (Haptophyta) in outdoor raceway ponds. Journal of Applied Phycology. 18: 703-712. DOI: https://doi.org/10.1007/s10811-006-9075-1.

Moheimani N.R., Webb J.P. \& Borowitzka M.A. 2012. Bioremediation and other potential applications of coccolithophorid algae: a review. Algal Research. 1: 120-133. DOI: https://doi.org/10.1016/j.algal.2012.06.002.

Monteiro F.M., Bach L.T., Brownlee C., Bown P., Rickaby R.E.M, Poulton A.J., Tyrrell T., Beaufort L., Dutkiewicz S., Gibbs S., Gutowska M.A., Lee R., Riebesell U., Young J. \& Ridgwell A. 2016. Why marine phytoplankton calcify. Science Advances. 2: article e1501822. DOI: https://doi.org/10.1126/sciadv.1501822.

Moore D., Heilweck M. \& Petros, P. 2021. Saving the Planet with Appropriate Biotechnology: 1. Diagnosing the Problems/Salvando el planeta con biotecnología apropiada: 1. Diagnóstico de los problemas. Mexican Journal of Biotechnology. 6(1): 1-30. DOI: https://doi.org/10.29267/mxjb.2021.6.1.1.

Moore T.S., Dowell M.D. \& Franz B.A. 2012. Detection of coccolithophore blooms in ocean color satellite imagery: a generalized approach for use with multiple sensors. Remote Sensing of Environment. 117: 249-263. DOI: https://doi.org/10.1016/..rse.2011.10.001.

Morrissey J.F., Sumich J.L. \& Pinkard-Meier D.R. 2016. Introduction to the Biology of Marine Life. 11th revised edition. Pp. 450. Burlington, MA, USA: Jones and Bartlett Publishers, Inc. ISBN: 9781284090505.

Müller M.N. 2019. On the genesis and function of coccolithophore calcification. Frontiers in Marine Science. 6: article 49. DOI: https://doi.org/10.3389/fmars.2019.00049.

Müller M.N., Barcelos e Ramos J., Schulz K.G., Riebesell U., Kaźmierczak J., Gallo F., Mackinder L., Li, Y., Nesterenko P.N., Trull T.W. \& Hallegraeff G.M. 2015. Phytoplankton calcification as an effective mechanism to alleviate cellular calcium poisoning. Biogeosciences. 12: 6493-6501. DOI: https://doi.org/10.5194/bg-12-6493-2015.

Narala R.R., Garg S., Sharma K.K., Thomas-Hall S.R., Deme M., Li, Y. \& Schenk P.M. 2016. Comparison of microalgae cultivation in photobioreactor, open raceway pond, and a two-stage hybrid system. Frontiers in Energy Research. 4: article 29. DOI: https://doi.org/10.3389/fenrg.2016.00029. 
Nomura M., Atsuji K., Hirose K., Shiba K., Yanase R., Nakayama T., Ishida K.-i. \& Inaba K. 2019. Microtubule stabilizer reveals requirement of $\mathrm{Ca}^{2+}$-dependent conformational changes of microtubules for rapid coiling of haptonema in haptophyte algae. Biology Open. 8: article bio036590. DOI: https://doi.org/10.1242/bio.036590.

Okada H. \& Susumu H. 1973. The distribution of oceanic coccolithophores in the Pacific. DeepSea Research and Oceanographic Abstracts. 20: 355-374. DOI: https://doi.org/10.1016\%2F0011-7471\%2873\%2990059-4.

Perrin L., Probert I., Langer G. \& Aloisi G. 2016. Growth of the coccolithophore Emiliania huxleyi in light- and nutrient-limited batch reactors: relevance for the BIOSOPE deep ecological niche of coccolithophores. Biogeosciences. 13: 5983-6001. DOI: https://doi.org/10.5194/bg-13-59832016.

Probert I. \& Houdan A. 2004. The laboratory culture of coccolithophores. Pp. 217-249, in: Coccolithophores: From Molecular Processes to Global Impact, (eds H.R. Thierstein \& J.R. Young). Berlin, Heidelberg: Springer. ISBN: 9783540219286. DOI: https://doi.org/10.1007/9783-662-06278-4 9.

Qureshi N., Annous B.A., Ezeji T.C., Karcher P. \& Maddox I.S. 2005. Biofilm reactors for industrial bioconversion processes: employing potential of enhanced reaction rates. Microbial Cell Factories. 4: 24 DOI: https://doi.org/10.1186/1475-2859-4-24.

Raven J. A. \& Crawfurd K. 2012. Environmental controls on coccolithophore calcification. Marine Ecology Progress Series. 470: 137-166. DOI: https://doi.org/10.3354/meps09993.

Read B.A., Kegel J., Klute M.J., Kuo A., Lefebvre S.C. and 34 others. 2013. Pan genome of the phytoplankton Emiliania underpins its global distribution. Nature. 499: 209-213. DOI: https://doi.org/10.1038/nature12221.

Rincon S.M., Romero H.M., Aframehr W.M. \& Beyenal H. 2017. Biomass production in Chlorella vulgaris biofilm cultivated under mixotrophic growth conditions. Algal Research. 26: 153-160. DOI: https://doi.org/10.1016/i.algal.2017.07.014.

Saavedra-Pellitero M. , Baumann K.H. , Flores J.A. \& Gersonde R. 2014. Biogeographic distribution of living coccolithophores in the Pacific sector of the Southern Ocean. Marine Micropaleontology. 109: 1-20. DOI: https://doi.org/10.1016/i.marmicro.2014.03.003.

Sachdeva R., Kaur R. \& Sangha J.K. 2004. Effect of supplementation of Spirulina on the haematological profile and intellectual status of school girls (7-9 years). Journal of Human Ecology. 15: 105-108, DOI: https://doi.org/10.1080/09709274.2004.11905674.

Sáez A.G., Probert I., Young J.R., Edvardsen B., Eikrem W. \& Medlin L.K. 2004. A review of the phylogeny of the Haptophyta. Pp. 251-269. In: Coccolithophores: From Molecular Processes to Global Impact, (eds H.R. Thierstein \& J.R. Young). Berlin, Heidelberg: Springer. ISBN: 9783540219286. DOI: https://doi.org/10.1007/978-3-662-06278-4 10.

Schwab G.O., Fangmeier D.D. \& Elliot W.I.E. 1996. Soil and water management systems. 4th edition. Hoboken, NJ, USA: John Wiley \& Sons Inc. ISBN: 9780471109730. 384 Pp.

Self-Trail J.M., Powars D.S., Watkins D.K. \& Wandless G.A. 2012. Calcareous nannofossil assemblage changes across the Paleocene-Eocene Thermal Maximum: evidence from a shelf 
setting

Marine

Micropaleontology.

92-93:

61-80.

DOI:

https://doi.org/10.1016/i.marmicro.2012.05.003.

Siegelman H.W. \& Guillard R.R.L. 1971. Large-scale culture of algae. Methods in Enzymology. 23: 110-115. DOI: https://doi.org/10.1016/S0076-6879(71)23085-8.

Simkiss K. 1977. Biomineralization and detoxification. Calcified Tissue Research. 24: 199-200. DOI: https://doi.org/10.1007/BF02223316.

Skeffington A.W. \& Scheffel A. 2018. Exploiting algal mineralization for nanotechnology: bringing coccoliths to the fore. Current Opinion in Biotechnology. 49: 57-63. DOl: https://doi.org/10.1016/j.copbio.2017.07.013.

Smith H.E.K., Tyrrell T., Charalampopoulou A., Dumousseaud C., Legge O.J. and 9 others. 2012. Predominance of heavily calcified coccolithophores at low $\mathrm{CaCO}_{3}$ saturation during winter in the Bay of Biscay. Proceedings of the National Academy of Sciences of the United States of America. 109: 8845-8849. DOI: https://doi.org/10.1073\%2Fpnas.1117508109.

Taylor A.R., Brownlee C. \& Wheeler G. 2017. Coccolithophore cell biology: chalking up progress. Annual Review of Marine Science. 9: 283-310. DOI: https://doi.org/10.1146/annurevmarine-122414-034032.

Thierstein H.R. \& Young J.R. (eds). 2004. Coccolithophores: From Molecular Processes to Global Impact. ISBN: 9783540219286. DOI: https://doi.org/10.1007/978-3-662-06278-4.

Torrey M. 2010. Survey of commercial developments of microalgae as biodiesel feedstock. Pp. 243-270. In: Single Cell Oils (Second Edition), (eds Z. Cohen \& C. Ratledge). Urbana, IL, USA: American Oil Chemists Society (AOCS) Press, an imprint of Elsevier Inc. ISBN 9781893997738. DOI: https://doi.org/10.1016/B978-1-893997-73-8.50016-5.

Tuomisto H.L. 2010. Food security and protein supply - cultured meat a solution? Aspects of Applied Biology, 102: 99-104. URL: http://static.elmercurio.cl/.

Ugwu C.U., Aoyagi H. \& Uchiyama H. 2008. Photobioreactors for mass cultivation of algae. Bioresource Technology. 99: 4021-4028. DOI: https://doi.org/10.1016/j.biortech.2007.01.046.

Ullah K., Ahmad M., Sofia Sharma V.K., Lu P., Harvey A., Zafar M., Sultana S. \& Anyanwu C.N. 2014. Algal biomass as a global source of transport fuels: overview and development perspectives. Progress in Natural Science: Materials International. 24: 329-339. DOI: https://doi.org/10.1016/i.pnsc.2014.06.008.

Vardi A., Haramaty L., Van Mooy B.A.S., Fredricks H.F., Kimmance S.A., Larsen A. \& Bidle K.D. 2012. Host-virus dynamics and subcellular controls of cell fate in a natural coccolithophore population. Proceedings of the National Academy of Sciences of the United States of America. 109: 19327-19332. DOI: https://doi.org/10.1073/pnas.1208895109.

Vicente B., Cachão M., David H., Silva J.L., Tenreiro A. \& Amorim A. 2019. Coccolithophores, a green technology for mitigation of carbon emissions. Poster at IMMR'18, International Meeting on Marine Research 2018. DOI: https://doi.org/10.3389/conf.FMARS.2018.06.00034.

Walker C.E., Taylor A.R., Langer G., Durak G.M., Heath S., Probert I., Tyrrell T., Brownlee C. \& Wheeler G.L. 2018. The requirement for calcification differs between ecologically important 
coccolithophore species. New Phytologist. 220: 147-162. DOI: https://doi.org/10.1111/nph.15272.

Winter A., Jordan R.W. \& Roth P.H. 2006. Biogeography of living coccolithophores in ocean waters. In: Coccolithophores, (eds A. Winter \& W.G. Siesser). 256 pp. Cambridge, UK: Cambridge University Press. ISBN: 9780521031691. URL: https://www.cambridge.org/.

Winter A. \& Siesser W.G. 2006. Coccolithophores. 256 pp. Cambridge, UK: Cambridge University Press. ISBN: 9780521031691 . URL: https://www.cambridge.org/.

Xu L., Weathers P.J., Xiong X.-R. \& Liu C.-Z. 2009. Microalgal bioreactors: challenges and opportunities. Engineering in Life Sciences. 9: 178-189. DOI: https://doi.org/10.1002/elsc.200800111.

Young J.R., Andruleit H. \& Probert I. 2009. Coccolith function and morphogenesis: insights from appendage-bearing coccolithophores of the family syracosphaeraceae (haptophyta). Journal of Phycology. 45: 213-226. DOI: https://doi.org/10.1111/i.1529-8817.2008.00643.x.

Yunev O.A., Carstensen J., Moncheva S., Khaliulin A., ÆErtebjerg G. \& Nixon S. 2007. Nutrient and phytoplankton trends on the western Black Sea shelf in response to cultural eutrophication and climate changes. Estuarine, Coastal and Shelf Science. 74: 63-76. DOI: https://doi.org/10.1016\%2Fj.ecss.2007.03.030. 